\title{
Linking Women's Participation and Benefits within the Namibian Community Based Natural Resource Management Program
}

\author{
Selma Lendelvo ${ }^{1}$, Faith Munyebvu ${ }^{1} \&$ Helen Suich ${ }^{2,3}$ \\ ${ }^{1}$ Life Sciences Division, Multidisciplinary Research Centre, University of Namibia, Windhoek, Namibia \\ ${ }^{2}$ Environmental Change Institute, School of Geography and the Environment, University of Oxford, Oxford, \\ England \\ ${ }^{3}$ Crawford School of Public Policy, Australian National University, Canberra, Australia \\ Correspondence: Selma Lendelvo, Life Sciences Division, Multidisciplinary Research Centre, University of \\ Namibia, Private Bag 13301, Windhoek, 340 Mandume Ndemufayo Avenue, Namibia. Tel: 264-61-206-3051. \\ E-mail: slendelvo@unam.na
}

Received: October 2, 2012 Accepted: November 6, 2012 Online Published: November 19, 2012

doi: $10.5539 /$ jsd.v5n12p27

URL: http://dx.doi.org/10.5539/jsd.v5n12p27

\begin{abstract}
Women are important resource users and managers and their participation in community based natural resource management activities can create a platform for their empowerment and enhance their role in decision-making, including benefit sharing. The purpose of this paper is to examine the levels of participation of women in activities Namibia's communal area conservancies and the benefits they receive. The study was carried out in four conservancies in Namibia. It reveals that women participate in diverse activities. With respect to conservancies, women's participation appears to be highest in conservancy activities where their satisfaction levels with conservancy benefits are highest. Further, women from older and less populated conservancies prioritize conservancy activities above general community engagements. Benefits to women were conservancy-specific, although game meat emerged as a prominent benefit to all conservancies. Allowing women to actively participate in initiatives that are related to their traditional roles is essential in enhancing women's participation and improved benefits, and is desired by women in all of the conservancies studied.
\end{abstract}

Keywords: women, conservancy, participation, benefits, Namibia, community based natural resource management

\section{Introduction}

Community-based conservation is regarded as a practical approach to stemming biodiversity loss in developing countries (Mehta \& Kellert, 1998; Munthali, 2007). The community based natural resource management (CBNRM) program in Namibia is one such example, where the sustainable use and conservation of biodiversity aims to allow local communities to derive direct benefits from their wildlife management efforts (Paterson et al., 2008). These benefits, (e.g. income, employment, skills, etc.) are most often derived from tourism activities (e.g. photographic tourism and/or trophy hunting), but can also be derived from other activities including hunting for own use, etc. The Namibian program has developed a reputation as one of the leading community based conservation initiatives in southern Africa (Jones \& Mosimane, 2000; Jones, 2010).

While conservancies (as these Namibian community conservation areas are known) are formed to both protect biodiversity and provide opportunities for benefits to members, participation is recognized as an essential principle for any CBNRM initiative (Jones \& Mosimane, 2000). This is because participation is expected to generate quality and durable decisions (Reed, 2008), while local stakeholders are assumed to be more likely to maintain their participation if they are assured that their input in collective efforts will provide them with benefits (Nuggehalli \& Prokopy, 2009).

The degree to which stakeholders participate and are engaged can be thought of along a continuum of increasing stakeholder participation - participation shifts from nominal levels to interactive or empowering levels (Table 1) (Flintan, 2008; Reed, 2008). Shifts along this continuum should be underpinned by the philosophy of empowerment, equity, trust and learning (Reed, 2008), and in the latter cases, participants have a voice and influence in group decisions as well as holding leadership positions (Agarwal, 2010). With respect to CBNRM 
initiatives, self-mobilization is the desirable level of participation (Flintan, 2008) as it is necessary to achieving ownership, continuous participation and acquisition of knowledge, and allows participants to make choices on whether and how to participate (Sanderson \& Kindon, 2004).

Table 1. Levels of participation

\begin{tabular}{|c|c|}
\hline Form/level of participation & Characteristic features \\
\hline Nominal participation & Membership in the group \\
\hline Passive participation & $\begin{array}{l}\text { Being informed of decisions ex post facto; or attending meetings } \\
\text { and listening in on decision making without speaking up }\end{array}$ \\
\hline Consultative participation & $\begin{array}{l}\text { Being asked an opinion in specific matter without guarantee of } \\
\text { influencing the decisions }\end{array}$ \\
\hline Activity-specific participation & Being asked (or volunteering) to undertake specific tasks \\
\hline Active participation & $\begin{array}{l}\text { Expressing opinions, whether solicited or not, or taking } \\
\text { initiatives of other sorts }\end{array}$ \\
\hline Interactive (empowering) participation & $\begin{array}{l}\text { Having voice and influence in group decisions; holding positions } \\
\text { as office bearers }\end{array}$ \\
\hline Self-mobilization & $\begin{array}{l}\text { Communities participate by taking initiatives independent of } \\
\text { external institutions to change systems; external agents may play } \\
\text { a facilitating or catalytic role }\end{array}$ \\
\hline
\end{tabular}

Source: modified from Agarwal (2010) and Flintan (2008).

Participation can also be viewed as either 'planner-centered' which puts emphasis on outcomes, or 'people-centered' which deals with capacity building and empowerment of stakeholders in order to meet their needs (Reed, 2008; Nuggehalli \& Prokopy, 2009). People-centered approaches are said to enable both men and women have equal potential to participate (Das, 2011), and gender balance in decision-making authorities for collective action is recognized as having both equity and efficiency implications.

In practice, the roles and responsibilities of men and women in different parts of the world are shaped and defined by socio-cultural norms and traditions, and in part by their involvement in different kinds of resource use activities. Many of the products women depend on in traditional societies are relatively frequently needed and are often non-monetized, such as firewood, medicinal and edible products. In contrast, men often have control over resources that are used less regularly but that are able to generate larger incomes, such as timber and wildlife (Rozemeijer \& van der Jagt, 2000; Agarwal, 2010; Das, 2011).

In traditional societies, women are often disinclined to participate in activities that are seen to go against these traditionally defined roles (Nuggehalli \& Prokopy, 2009), which can present obstacles to participation in conservation efforts. Further, in cases where participation is characterized by unequal power relationships, this will also have an impact on available livelihood options, decision-making abilities and development outcomes. Where the voices of marginalized groups are co-opted or are unable to be expressed openly because of a dominant leadership, this may affect the outcomes of natural resources management (Cooke, 2001; Maconachie, 2010).

With respect to the Namibian CBNRM program, activities to explicitly encourage women's participation started in 1994, even before the communal conservancy legislation was enacted, with the creation of community resource monitor (CRM) posts (Jacobsohn \& Owen-Smith, 2003). This followed a period of CBNRM development where women had not been taken into consideration (Flintan, 2001). However, the CRM posts gave women an opportunity to become involved in CBNRM and manage the resources from which they derived direct income, as well as giving women a means of accessing information and a forum for influencing decision-making (Flintan, 2001). The CRM program remains active, particularly in the Caprivi region, with more than 30 women working in their conservancies. The activities implemented by the CRMs include: linking local craft producers to markets; awareness raising and educating other women about sustainable harvesting of resources; running HIV/AIDS peer education programs; participating in anti-poaching and human-wildlife conflict activities and in game counts within their conservancies. These women are also exposed to public speaking training to build confidence and assertiveness when executing their work (Matota, personal communication, 23 October 2012). 
While the conservancy legislation requires equal opportunities to participate for all community members, it does not explicitly incorporate gender requirements. However, while the importance of women as full participants in natural resources management is recognized, it has been argued that the continuation of male-dominated leadership structures hinders active participation of women in the Namibian CBNRM program (Flintan, 2003). Questions have also been raised about the extent of women's integration into CBNRM activities and leadership, and whether separation along gender lines compromises the ability of women to contribute to traditionally male domains of decision making (Sullivan, 2002).

The purpose of this paper is therefore to examine the participation of women in activities of conservancies, and the relationship between the benefits they receive and their participation levels. This paper describes a number of activities in which women participate - including by involvement in leadership committees - and the factors affecting their participation, to help identify the factors leading to empowering engagements.

\section{Methods}

\subsection{Study Sites}

This study focuses on the conservancies located on communal lands in Namibia. At present, there are 76 conservancies currently registered with the Ministry of Environment and Tourism - that is, those that are formally recognized by government as community institutions for natural resource management (Namibian Association of CBNRM Support Organizations [NACSO], 2012). Four conservancies were selected as study sites: Orupembe, Mashi, Torra and King Nehale (Figure 1 and Table 2). They were selected to reflect a range of different experiences, arising from their different locations (i.e. with different wildlife and other natural resources, different livelihood activities of residents and different cultural practices of natural resource utilization), length of conservancy operation (i.e. with different levels of awareness among residents, where older conservancies were expected to have greater awareness amongst residents), revenue generated and ability to cover operating costs (representing a probable difference in the value and quantity of benefits distributed).

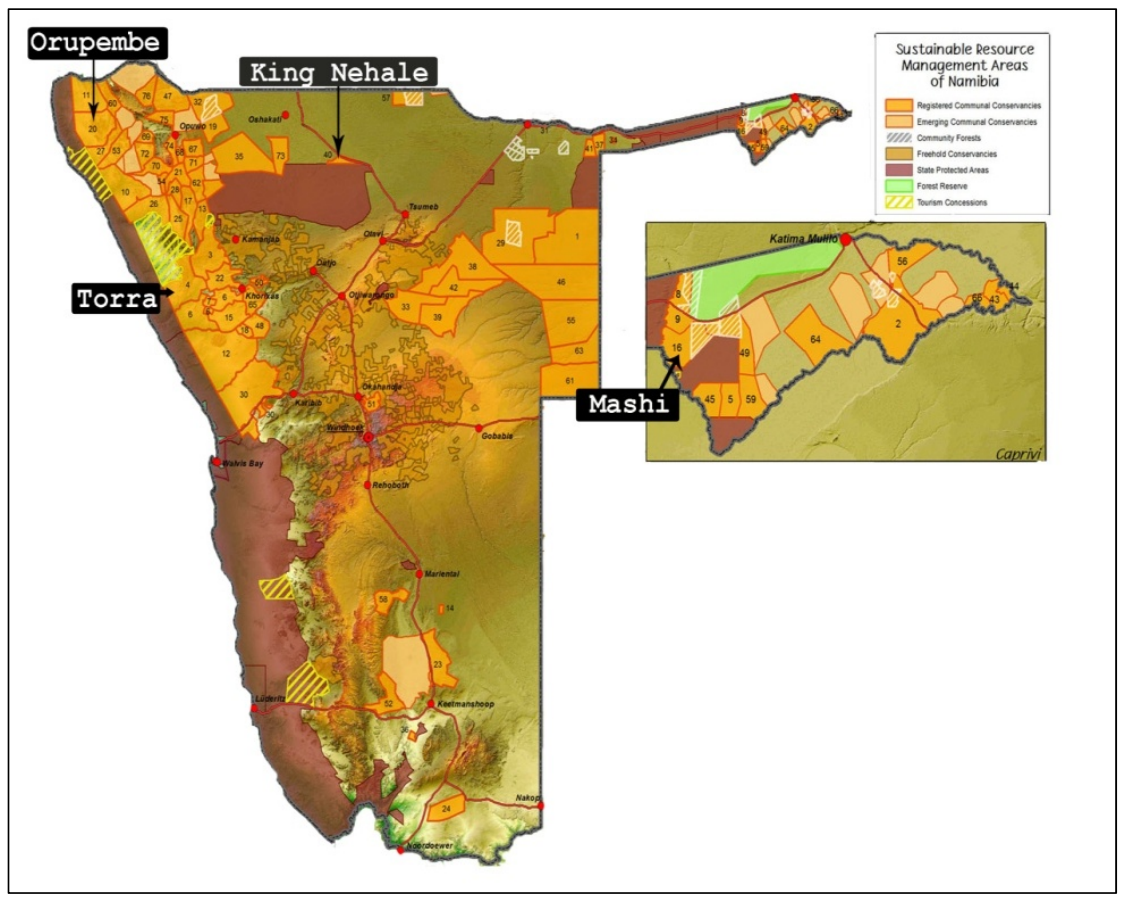

Figure 1. Map of the Namibian conservancies

The main activities of Orupembe Conservancy are a joint venture tourism agreement, trophy hunting, a conservancy campsite, hunting for own use, resource harvesting and craft production (the latter especially by women). The main livelihood activities of women in Orupembe are based on livestock and Commiphora harvesting and sales. Torra Conservancy was among the first conservancies to be registered in Namibia. The conservancy engages in joint venture tourism and trophy hunting, the live sale of springbok, shoot and sell hunting and own-use hunting. The two most important livelihood activities are livestock-keeping and 
employment. Mashi Conservancy is involved in various resource management activities such as trophy hunting, craft production, thatching grass sales, eco-tourism and resource monitoring. The most important livelihood activities for women in Mashi are cropping, craft sales and employment. King Nehale Conservancy is located in the most densely populated region of the country, and is located north of the largest national park in Namibia, Etosha National Park. The conservancy has a craft shop, and is involved in trophy hunting, Kalahari melon seed sales and craft production. Livelihoods are based on cropping, small (informal) business and livestock.

Table 2. Conservancy characteristics

\begin{tabular}{|c|c|c|c|c|}
\hline & Orupembe & Torra & Mashi & King Nehale \\
\hline Region & Kunene & Kunene & Caprivi & Oshikoto \\
\hline Registration & 2003 & 1998 & 2003 & 2005 \\
\hline Size $\left(\mathrm{km}^{2}\right)$ & 3,565 & 3,522 & 297 & 508 \\
\hline Habitat & $\begin{array}{l}\text { Less than } 100 \mathrm{~mm} \\
\text { rainfall p.a., largely } \\
\text { semi-desert and } \\
\text { sparse savannah }\end{array}$ & $\begin{array}{l}\text { Less than } 100 \mathrm{~mm} \\
\text { rainfall p.a., largely } \\
\text { semi-desert and } \\
\text { sparse savannah }\end{array}$ & $\begin{array}{l}\text { Approx. } 600 \mathrm{~mm} \\
\text { rainfall p.a., } \\
\text { Kalahari } \\
\text { woodlands and } \\
\text { floodplains }\end{array}$ & $\begin{array}{l}400-500 \mathrm{~mm} \\
\text { rainfall p.a., } \\
\text { woodland, } \\
\text { grasslands and } \\
\text { mixed thorn bush }\end{array}$ \\
\hline Population (approx.) & 400 & 1,200 & 3,900 & 20,000 \\
\hline $\begin{array}{l}\text { Number of households } \\
\text { (approx.) }\end{array}$ & 100 & 300 & 600 & 4,000 \\
\hline $\begin{array}{l}\text { Female-headed } \\
\text { households }(\%)^{*}\end{array}$ & 36 & 45 & 50 & 52 \\
\hline $\begin{array}{l}\text { Main languages } \\
\text { spoken }\end{array}$ & ovaHimba & Afrikaans, Damara & Sifwe, Mbukushu & Oshiwambo \\
\hline $\begin{array}{l}\text { Conservancy } \\
\text { committee } \\
\text { membership in } 2009 \text {, } \\
\text { total members } \\
\text { (women) }\end{array}$ & $12(6)$ & $8(1)$ & $12(1)$ & $32(20)$ \\
\hline
\end{tabular}

* A female-headed household refers to the de jure household head which is considered to be the permanent head of a particular household, based on status: single, divorced, separated or widowed (Hossain \& Huda, 1995).

Sources: Government of Namibia, 2003; NACSO, 2006, 2008 and 2010.

\subsection{Data Collection Methods}

This study used both quantitative and qualitative research methods in the implementation of a household questionnaire survey aimed at female-headed households, which collected information about household demography, sources of income, livelihood activities, participation in and benefits derived from the conservancy. Group discussions were also held with women in each of the four conservancies. In order to avoid researcher bias, the research instruments were developed and piloted before the actual data collection and trained enumerators were recruited for the data collection. All analysis was conducted by more than one researcher to reduce bias during interpretation and to ensure neutrality.

\subsubsection{Sampling Strategy for the Questionnaire Survey}

The population this study focused on is female-headed households. A two stage sampling strategy was used first to select villages, and then households within those villages. Within each conservancy, villages were selected based on their distances from the conservancy office or centre. This was done to ensure views from women across the conservancy were included, as it was thought that perceptions among women living closer to the conservancy centre or where the office is located may differ from those living further from the conservancy (Naanda, 1998). A non-probability sampling method was used to select the sample of female-headed households for this study (Babbie, 2010). In each of the selected villages, researchers identified female-headed households with the help of the traditional authority of the village. From this list, households were then randomly selected by 
enumerators for interview. A total of 131 households were interviewed: Orupembe (27), Torra (25), Mashi (25) and King Nehale (54).

The principal respondents in this study were women and girls. $118(90 \%)$ of respondents were adult female heads of households, and six (five percent) were girl-headed households (when a household was selected and was led by a girl-less than 18 years of age - it was eligible to be interviewed as it was considered to be female-headed). Seven (five percent) of the respondents were (adult) males, as the female head was not available for interview at the time of the fieldwork (in late 2008). The sample size is too small to conduct statistical tests for differences in perceptions between different groups within conservancies (e.g. social, wealth or ethnic groups), or between female- or girl-headed households.

It should be noted that the sample size used in this research is too small to enable the results presented below to be thought of as representative of all women in conservancies. However this research has enabled a useful and novel examination of the range of perceptions and understandings of women regarding their participation in, and benefit from, conservancy activities.

\subsubsection{Group Discussions}

The Nominal Group Technique (NGT) was used to collect data from women and girls in groups. The NGT can be used as a tool for constructing a consensus (Ritchie, 1985) as it is a structured process for generating ideas where individuals produce ideas in isolation and then share them with the group. It enables groups to equitably prioritize ideas without intimidation from other group members (Zinn et al., 2010). A question guide was developed to facilitate the group discussions, and five groups of women were selected, consisting of between five and seven participants for each conservancy. Three group discussions were held in each conservancy in different locations. The purpose of using this technique was to strengthen and validate information from the questionnaire survey, by discussing the main questions in the questionnaire at these group discussions. However, it should be noted that in the results presented below, data relates to that collected in the household survey, unless otherwise specified.

\section{Results}

\subsection{Profile of the Household Heads}

Table 3 shows the key characteristics of the households interviewed in the four conservancies. It can be seen from the table that there are differences in each of the key characteristics of the household types.

Table 3. Key characteristics of sampled households

\begin{tabular}{|c|c|c|c|c|}
\hline & Orupembe & Torra & Mashi & $\begin{array}{l}\text { King } \\
\text { Nehale }\end{array}$ \\
\hline Average age of household head & 45 & 32 & 47 & 39 \\
\hline \multicolumn{5}{|c|}{ Highest educational attainment of household member (\%) } \\
\hline - $\quad$ None & 80 & 2 & 24 & 5 \\
\hline - $\quad$ Grade $1-5$ & 18 & 22 & 38 & 19 \\
\hline - $\quad$ Grade 6-9 & 2 & 54 & 34 & 61 \\
\hline - $\quad$ Grade $10-12$ & 0 & 18 & 3 & 12 \\
\hline - Tertiary or vocational education & 0 & 4 & 1 & 3 \\
\hline Average household size & 4 & 6 & 4 & 7 \\
\hline Average household income (N\$) & 490 & 1,075 & 285 & 510 \\
\hline $\begin{array}{l}\text { Average proportion of dependents (i.e. memb } \\
\text { than } 65)(\%)\end{array}$ & 46 & 40 & 40 & 38 \\
\hline \multicolumn{5}{|l|}{ Occupation of household head (\%) } \\
\hline - $\quad$ Farmer/pastoralist & 85 & 9 & 27 & 56 \\
\hline - Conservancy employee/committee & - & 16 & 16 & - \\
\hline - $\quad$ Tourism (lodges and campsites) & - & 16 & - & - \\
\hline - $\quad$ Self-employed & 4 & 8 & - & 16 \\
\hline - Pensioner & - & 4 & - & 9 \\
\hline - $\quad$ Unemployed (looking for a job) & - & 27 & 44 & 13 \\
\hline - Other formal employment & - & 20 & 13 & - \\
\hline - $\quad$ Staying at home (not looking for work) & 11 & - & - & 6 \\
\hline
\end{tabular}




\subsection{Traditional Utilization of Natural Resources by Women}

During the group discussions, women described traditional natural resource utilization activities, some of which they generate income from. The most common activities in which Orupembe women participate is making lotions from Commiphora wildii resin, from ochre and harvesting plants for medicinal purposes (e.g. mopane leaves to cure diarrhea, Hoodia spp. to cure high blood pressure).

Orupembe conservancy runs a project to ensure sustainable, commercial, Commiphora resin harvesting. The project was initiated by a non-government organization (NGO) facilitating conservancy activities, and resulted in an historic agreement made in 2010 between the Kunene Commiphora Conservancy Association (Orupembe and four other conservancies) and a South African company, to buy commercially harvested Commiphora resin. The agreement will run for five years, governs the sustainable harvesting and utilization of the resource by harvesters and guarantees purchases of harvested resin, representing a considerable and relatively long-term source of revenue for local (mostly women) harvesters (Ministry of Environment and Tourism [MET], 2010).

With respect to natural resource utilization, women in King Nehale Conservancy were primarily involved in the extraction of oil from Kalahari melon seeds (Cirullus lanatus) for use in cooking, as a lotion and for healing/massage purposes. Some women also harvest Marula fruit and kernels, and may generate income from these products, as well as from the production and sale of crafts (e.g. clay pots and woven baskets). Most of these activities are not specifically related to the conservancy, though some women do sell their crafts through the conservancy craft shop.

In Mashi Conservancy, the common traditional activities mentioned by the women included harvesting of reeds and other plant products for craft production-mostly of baskets. The conservancy facilitates the sale of these crafts at the nearby Mashi Craft Market and other sales outlets in Namibia, and they have, with NGOs, historically been important in building capacity for craft production and marketing.

Women in Torra Conservancy stated that their traditional utilization of resources was primarily the use of medicinal plants, though the conservancy is not formally involved in these harvesting and subsistence use activities.

\subsection{Women's Participation in Conservancy Activities}

Women were requested to identify activities they had participated in, in their conservancies over the previous five years, over and above their normal household duties. The purpose of this was to improve understanding on the range of activities in which women participated in addition to their households' core activities. These activities were subsequently grouped into three categories, two of which reflected voluntary activities - namely, community development and conservancy-specific activities. Community development activities included activities driven by government and other development institutions (e.g. water management, agricultural training, support groups and training on orphans and HIV/AIDS, and other health related activities, cultural upliftment, fund-raising and skills development). Conservancy specific activities were those organized by either the conservancy or supporting NGOs. These activities included attending workshops, meetings and training, liaising (community visits and interactions with relevant stakeholders), resource management, membership registration, planning, attending functions of the conservancy, involvement in fire management, employment, tourism operations, office administration and dissemination of information and other conservancy specific projects such as crafts and natural resources projects. Enterprise activities or self-employment activities were also identified as important activities outside of the household, though they are somewhat different because of the private nature of the benefits of these activities. 


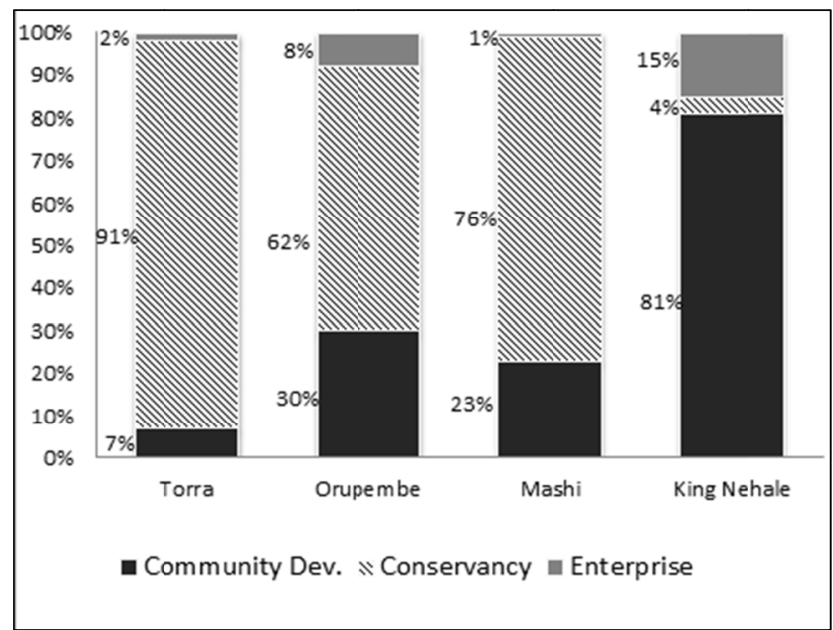

Figure 2. The activities women participated in over the past five years

With respect to women's participation in these three activity groups, King Nehale displays a very different picture from the participation of women in the other conservancies (Figure 2). Women in King Nehale had comparatively high levels of involvement in community development and enterprise activities but were less engaged in conservancy specific activities. Women in Mashi, Torra and Orupembe conservancies were relatively more involved in conservancy specific activities-either in income generation (i.e. craft production, Commiphora projects and harvesting of other natural resources or casual employment with tourism enterprises), meeting attendance, training activities or serving on conservancy committees.

Similar patterns were found with respect to women's participation in conservancy meetings (Figure 3) and attendance of training programs organized by conservancies.

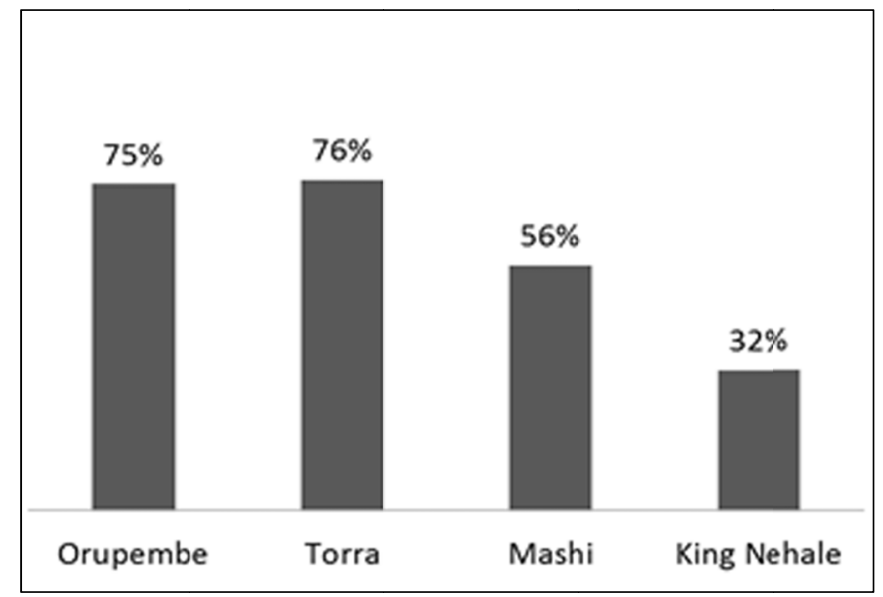

Figure 3. Women attending conservancy meetings in the four conservancies

The meetings referred to in Figure 3 were those organized by the conservancy, including ordinary and emergency meetings, annual and planning meetings, as well as meetings about specific projects. Torra women were particularly active in attending conservancy meetings. The women ensured their presence at these meetings because there are frequently discussions held, or announcements made during these meetings that may affect them, such as the provision of information about employment, business or training opportunities. Women in Torra stated therefore, that their attendance at such meetings was important so they could make their contribution and get correct information. The high value of the Commiphora project to women in Orupembe means that they try to attend all conservancy meetings, because it is at these meetings they hear about project developments and, despite their heavy domestic workload, women make time to attend meetings because this project mainly focuses on women and benefits for them. 
In Mashi, women indicated that they had attended meetings more frequently in the past, but more recently had decided to attend only those meetings where issues related to crafts or harvesting reeds and grass were discussed. The reasons given for attending fewer meetings were that men discriminate against women, that the traditional leadership does not seem to support them, and that benefits are not fairly distributed, reducing their incentives to participate. The low level of participation in conservancy meetings by women in King Nehale is partially because conservancy meetings are held less frequently than in other conservancies, and in many cases only area representatives attend. The women indicated that they attend meetings were they can see that things are moving and making an impact in their communities, but most meetings in King Nehale are feedback meetings and therefore offered less direct incentives to participate.

\subsection{Factors Affecting Levels of Participation}

According to the survey results, various factors affect the level of participation of women in conservancy activities. Among these were lack of interest among women (22\%), inadequate chances to participate (13\%), a lack of confidence among women (12\%) and the fact that women have not been elected to key positions (11\%). A lack of education and skills and of financial support, poor health and age, alcohol and drug abuse, and a lack of information sharing also emerged as factors affecting the participation of women in the four conservancies.

Several reasons emerged during discussions regarding the reasons why women felt they did not have an adequate chance to participate. Women felt they were not well informed about activities because notices about when and where meetings are to be held often relies on word of mouth. Further, many of the core conservancy activities are more strongly associated with male roles and responsibilities, reducing women's interest and involvement, compounded when specific platforms are not created to generate women's interest in these core activities. (These core activities relate primarily to wildlife management activities, including working as game guards, with hunting operations and to a lesser extent formal employment in (non-hunting) tourism enterprises). Indeed, in Mashi conservancy, one young woman indicated that she would like to be employed as a community game guard, but felt that only men are given such jobs in that conservancy.

Some women indicated that they could not actively participate because they did not have appropriate skill levels - in terms of literacy or educational attainments, or more specific skills necessary for some jobs such as game guards, hunters or tour guides. The lack of these skills also affected women's confidence in participating and asserting their desire to be involved. Concerns associated with not being elected to leadership positions were felt by women in all four conservancies, though these concerns were apparently felt more strongly by women in Orupembe and Mashi.

Some women also indicated that they did not have access to sufficient funds to cover transport and other costs which would enable their participation in activities, even those as seemingly mundane as attending meetings. Participation was also constrained by poor health and age limitations amongst elderly women and by alcohol and drug abuse by younger people.

Despite the factors that negatively affect their participation, women in all four conservancies indicated their wish to improve their participation in future, hoping to strengthen their participation in on-going activities and identifying activities which they hoped the conservancy would become involved in - including activities that bring individual returns and those that make a difference in their communities (see also discussion in Section 3.6).

\subsection{Conservancy Benefits}

Respondents were asked about the benefits derived from conservancy activities. Broadly, women viewed the establishment of the conservancy as a benefit because it resulted in the effective conservation and management of rangelands on which their livestock are dependent. Women also appreciated that they could now view different types of wildlife, even those they had only previously heard of, as a result of the improved management of wildlife and other natural resources. In Mashi conservancy, they indicated that wildlife in the area has provided job opportunities for local men as game guards.

The conservancies are also perceived by women as institutions that can bring empowerment to them. A range of different conservancy activities were mentioned to support this, including the knowledge gained during conservancy meetings, and the knowledge and experience gained in carrying out conservancy-related activities. In particular, the knowledge gained from the conservancy bringing people from different areas to build skills and capacity was highly valued. A Himba woman from Orupembe said: "I do not know how to read and write but I was taught how to harvest Commiphora resin using new ways and now I can do it myself. If they can continue to bring people to teach us even how start small projects to generate income for our families, we will learn". 
During the group discussions, women were also asked which of the benefits generated by the conservancies they considered to be the four most important. Game meat was identified as a benefit in all four conservancies-while game meat distributions are relatively small (households receive meat distributions of between five and 20 kilograms depending on the hunting effort), this is valued, in part because people had previously been deprived of legal access to game meat. The provision of employment and training opportunities were identified in three conservancies (Orupembe, Torra, \& Mashi). The Commiphora project was identified as important by the Orupembe women, the provision of transport by Torra women and money distributed to households was identified as important by the women in Mashi. The ladies of King Nehale were somewhat different in the benefits they believed were important, identifying sales of crafts and other natural products, and community development activities (e.g. improved access to clean water and training on farming and tourism attractions). The differences between these conservancies are related to the different activities undertaken in each of the four conservancies.

\subsection{Level of Satisfaction with Benefits}

Most women in Orupembe (73\%) and Torra (62\%) stated they were satisfied with the benefits they receive. In contrast, most women in Mashi $(85 \%)$ and King Nehale $(70 \%)$, stated that they were dissatisfied with the benefits they were receiving. When asked to provide more detail, women in Torra stated that they were satisfied because members of the conservancy were generally well-informed of different opportunities available. They also noted that they particularly valued the support given to every funeral that takes place within the conservancy (in terms of food and game meat for mourners, as well as transportation) and the transport to hospital provided for sick people within the conservancy. In the case of Orupembe, high levels of satisfaction with the benefits from the Commiphora project seems to be driving these generally high levels of satisfaction with the conservancy, and is one of the most important initiatives allowing women to get closer to the conservancy and its benefits.

The reasons for the levels of dissatisfaction were somewhat different between Mashi and King Nehale. In Mashi Conservancy, women felt that the level of delivered benefits was insufficient, and that the benefit distributions were inequitable. These women felt that benefit distribution decisions were taken without treating people from different tribal, socio-economic or age groups equally. They also noted that women and poor people in the community were discriminated against, and perceived that most benefits went to richer households. For example, one young woman stated that the conservancy "is very corrupt. Those closer to the conservancy and traditional leadership give themselves better benefits". These factors have negatively impacted on the levels of trust in the conservancy leadership.

When the reasons for the dissatisfaction amongst women in King Nehale Conservancy were explored further in group discussions, women identified the poor development in the area (e.g. poor road networks, unequal distribution of electricity, schools and water, no hospital), poor tourism operations, poor support to improve agricultural practices and limited job opportunities. With the exception of poor tourism operations, these responses suggest that many women from this area have some level of misunderstanding of the purpose of the conservancy and its ability to distribute benefits generated from wildlife management and utilization.

Women were also asked about what activities they wished the conservancy would undertake in future that would maximize their satisfaction. Overall, the types of activities identified were similar across the four conservancies, and can be grouped into four types. The first included the provision of services and/or information related to natural resource utilization, including: the establishment, improvement or expansion of tourism facilities, attracting more tourists and therefore improving tourism business profitability; compensation for the costs associated with human-wildlife conflict; training and skills development relevant to wildlife management, craft production and hospitality; and the provision of equipment for harvesting natural resources (e.g. reeds, thatching grass, wild foods, etc.). Other resource-based activities included agricultural extension to improve farming outputs and income; the provision of livestock to women and the poor so they could start farming; and agricultural input subsidies to improve agricultural profitability.

The second group of activities related to the provision of largely public goods, including activities as diverse as: the provision of schools and hospitals closer to villages; the provision of clean water; training in first aid; education programs for illiterate conservancy residents; and education subsidies. The third type of activity women desired incorporated general development opportunities, including employment creation and assistance (both training and financial) to start small enterprises (e.g. sewing, baking, trading, etc.). The fourth type incorporated a range of activities that could be interpreted as providing social security or welfare assistance, including: the provision of food, medicine and other basic needs for poor community members; financial support 
to the disabled and poor; financial assistance to communities and monthly grants to registered conservancy members; and the provision of support to orphans (e.g. paying school fees, transport costs, etc.).

When discussing these desired activities, women noted that the process of benefit distributions was important, particularly in Torra and Mashi, where women emphasized the need for equal distribution of conservancy benefits irrespective of gender, economic and ethic background.

\section{Discussion}

The results reveal that the participation levels and perceptions towards benefits were associated with distinctiveness of the four conservancies, in terms of their length of operation, culture and internal relations, population densities, tourism attractions and employment opportunities.

In Orupembe and Torra conservancies, the levels of participation in conservancy initiatives and satisfaction with benefits they received were comparatively high. The high levels of participation among women in Orupembe were mainly associated with the establishment of the project focusing on the sustainable harvesting of Commiphora wildii resin. This project is geared to value-addition, income generation and capacity building for women. Because project activities build on traditional resource utilizing activities, women feel able to participate actively without being constrained by poor educational or being negatively affected by male dominance (harvesting is not traditionally done by men, and activities take place with little male influence).

Torra Conservancy also had high levels of participation in conservancy initiatives and benefits they received. This high level of participation is mainly associated with conservancy efforts being seen as the most visible vehicle for development in the area - these women recognized and valued the wide range of benefits provided by the conservancy. Torra is one of the oldest conservancies in Namibia and is a partner in a number of high value tourism operations, which, when combined with low population, allows a greater range and value of benefits to be spread across a higher proportion of the population, which appears to have helped in raising the levels of contentment with the benefits.

While participation among Mashi Conservancy women was also quite high, this was mainly associated with what might be viewed as more traditional 'women's' activities, particularly craft sales, and to a lesser extent, the provision of some employment. However, there did not appear to be active participation in strategic decisions about conservancy management, and there was a high level of dissatisfaction with both the level of benefits received and the way in which the women perceived benefits to be distributed within the conservancy. This lack of trust in the conservancy and traditional leadership could be one of the key hindrances to active participation among women in Mashi in the future, if not addressed. This state of disillusionment among women in Mashi is a clear example of what Cooke (2001) termed as dysfunctional consensus caused by unequal power relationships. This highlights the importance of inclusion of all parties, minimizing any form of subordination and enabling the voice and knowledge of all participants to be heard (Sanderson \& Kindon, 2004).

Women's participation in conservancy activities in King Nehale is very low, primarily driven by the poor visibility of conservancy activities in the area - while the land area is relatively small, it has a very large human population (approximately 20,000 inhabitants). The difficulty of communicating with such a large membership and the relative newness of the conservancy are likely to have played a role in women's relatively poor understanding of the role of the conservancy, its potential for delivering benefits, and the type of benefits it may be able to deliver. Opportunities to harvest and sell products from their farms to the conservancy (e.g. Kalahari Melon and Marula seeds) were regarded as a main benefit for women, but it would seem that the benefit from these initiatives is too small to trigger higher levels of active participation more widely across conservancy activities.

A number of factors negatively affected the participation of women in the four conservancies, including a lack of interest among women, which is driven by the emphasis of conservancies on wildlife management, traditionally a male-dominated activity. Inadequate opportunities to participate, a lack of confidence among women, inadequate skills and resource constraints also reduced the ability of women to participate. However, conservancies could develop activities to address these factors, in order to provide opportunities for more active participation. The lack of effective influence of women in leadership positions was viewed by the women as a hindrance to the active participation of women. Low representation in Torra and Mashi conservancies could impede the voice of women in decision-making, and despite of high representation in committees in King Nehale and Orupembe conservancies, women are still dissatisfied with their involvement in leadership. This may suggest that women are elected to committees to make up numbers but are not yet empowered to influence decision-making. The levels of effective participation are directly linked to empowerment (Agarwal, 2010) which points to the potential for conservancies to achieve this by improving women's influence in 
decision-making processes. More intensive study of existing examples-such as the establishment of the Commiphora wildii resin project, which has paved a way for active participation in conservancy activities, because the project is run by women and women are benefiting from it-may provide opportunities for learning how to facilitate such change.

Despite the current low levels of participation, and arguably of benefits received, women felt that they would like to participate more in conservancy activities in the future and to benefit in the future from community conservation efforts. The types of desired future activities and benefits described by women were to be empowered through capacity building and financial support to meet their self-identified needs, but also to generate benefits of value to all conservancy members, not just themselves. The expression of these wishes demonstrates the desire of women to exercise of some control over decision making about conservancy management issues. These results therefore provide a starting point for program designers and implementers in designing activities to encourage the active participation of women, which would be likely to provide the appropriate incentives to encourage such participation, given that they would be based on the needs that women have themselves expressed. While the results of this research indicate a link between the benefits received and increasingly active participation by women, further research is necessary to analyze in detail the next steps particularly with respect to impacts on women's empowerment, conservancy management responsiveness to this increased participation, as well as the longer term impacts on conservation practices.

\section{Conclusion}

The strength of this research has been in examining the participation of women in non-domestic activities in their communities, focusing on their role in conservancy activities. It has shown that while women do participate in conservancy activities, active participation remains a challenge, though it is recognized that encouraging women to actively participate in projects where they are required to use and manage resources is a strategy towards women's empowerment that can be facilitated by conservancies. It is recognized that women (and indeed men) are likely to become actively involved in conservancy activities when their satisfaction levels with conservancy benefits are high. When the impact of benefits to households from conservancy efforts is limited, this generates dissatisfaction among members, reducing the likelihood of their future participation, which these results indicate may be compounded by strong male dominance in leadership structures. These factors have implications for effective participation among women. There is a need to develop strategies in order to improve communication, particularly within larger conservancies and more highly populated conservancies, and those with strong traditional leaderships, as well as to improve the level of benefits returned to members, and to improve the perceptions of benefit distribution processes.

This research indicates that men are still largely in control of decision-making processes within conservancies. Following the typology of participation outlined above, this research suggests that women are not yet able to participate interactively or self-mobilize, and that they are not yet equal partners with men in resource management. It is evident that increased participation opportunities for women in CBNRM can enhance direct and tangible benefits which are likely to lead to continuous participation and empowerment among women.

The results presented in this paper point to the need for further research regarding how to improve communication strategies about opportunities, means of participating, and benefits that might be derived from increasing participation. Further research is also needed to explore mechanisms to better understand the involvement of women in conservation efforts, and on how women's participation can be negotiated without such a strong focus on women's participation that emphasizes their domestic and traditional roles (e.g. in terms of plant harvesting, craft production, etc.).

\section{Acknowledgements}

We would like to begin by acknowledging our Almighty God for providing us with the strength and wisdom during the time we did the survey and produced this report. We appreciate the World Wildlife Fund in Namibia and the Multidisciplinary Research Centre of the University of Namibia for supporting this survey both technically and financially. Dr Patrick Graz has been our mentor during the development of this report and we appreciate his guidance and encouragement. In addition, we would also like to acknowledge Ms Patricia Skyer from WWF and Professor Steve McCool from the University of Montana for their guidance during production of this paper, as well as the excellent comments of the papers' anonymous reviewers. We also thank the enumerators who assisted us in collecting the data. Finally, we are indebted to the Conservancy Committees and community members of the four conservancies for giving us great support during the survey and report writing. 


\section{References}

Agarwal, B. (2010). Does women's proportional strength affect their participation? Governing local forests in South Asia. World Development, 38(1), 98-112. http://dx.doi.org/10.1016/j.worlddev.2009.04.001

Babbie, E. (2010). The Practice of Social Research (12th ed.). USA: Wadsworth Cengage learning.

Cooke, B. (2001). The social psychological limits of participation? In B. Cooke, \& U. Kothari (Eds.), Participation: The New Tyranny? London: Zed Books.

Das, N. (2011). Women's dependence on forest and participation in forestry: A case study of joint forest management program in West Bengal. Journal of Forest Economics, 17, 67-89. http://dx.doi.org/10.1016/j.jfe.2010.09.003

Flintan, F. (2001). Women and CBNRM in Namibia: A Case study of the IRDNC Community Resource Monitor Project. Engendering Eden Project Working Paper No. 2, The International Famine Centre, Ireland.

Flintan, F. (2003). Women, Gender and ICDPs in South and South-East Asia: Lessons Learnt and Experiences Shared. IIED Wildlife and Development Series No. 18, London.

Flintan, F. (2008). Women's empowerment in pastoral societies. WISP-IUCN, Ethiopia.

Government of Namibia. (2003). Report of Population and Housing Census of 2001. National Planning Commission, Windhoek.

Hossain, N., \& Huda, S. (1995). Problems of the Women Headed Households. Working Paper 9, The BRAC-ICDDR, Joint Research Project Dhaka, Bangladesh.

Jacobsohn, M., \& Owen-Smith, G. (2003). Integrating conservation and development: A Namibian case study. Nomadic Peoples, 7(1), 92-109. http://dx.doi.org/10.3167/082279403782088831

Jones, B. (2010). The evolution of Namibia's communal conservancies. In F. Nelson (Ed.), Community rights, conservation and contested land: The politics of natural resources governance in Africa. London: Earthscan.

Jones, B., \& Mosimane, A. (2000). Community-based natural resources management (CBNRM) in Botswana: How community based is CBNRM in Botswana? In S. Shackleton, \& B. Campbell (Eds), Empowering Communities to Manage Natural Resources: Case Studies from Southern Africa. South Africa: USAID SADC NRM.

Maconachie, R. (2010). New spaces' for change? Diamond governance reforms and the micro-politics of participation in post-war Sierra Leone. Public Administration and Development, 30(3), 191-202. http://dx.doi.org/10.1002/pad.558

Mehta, J. N., \& Kellert, S. R. (1998). Local attitudes toward community-based conservation policy and programs in Nepal: a case study in the Makalu-Barun Conservation Area. Environmental Conservation, 25(4): 320-333. http://dx.doi.org/10.1017/S037689299800040X

Ministry of Environment and Tourism. (2010). Historic access and benefit sharing (ABS) Agreement signed for Commiphora Resin. Earthbound Magazine, 5(2), 13.

Munthali, S. M. (2007). Transfrontier conservation areas: Integrating biodiversity and poverty alleviation in Southern Africa. Natural Resources Forum, 31, 51-60. http://dx.doi.org/10.1111/j.1477-8947.2007.00130.x

Naanda, M. T. (1998). Community knowledge, practice and attitude on community-based Natural Resource Management. A case study of the proposed Uukwaluudhi Conservancy, MRC Research reports, Windhoek.

NACSO. (2006). Namibia's communal conservancies: a review of progress and challenges in 2005. NACSO. Windhoek.

NACSO. (2008). Namibia's communal conservancies: a review of progress and challenges in 2007. NACSO. Windhoek.

NACSO. (2010). Namibia's communal conservancies: a review of progress and challenges in 2009. NACSO, Windhoek.

NACSO. (2012). Registered communal conservancies in Namibia, June 2012. Retrieved 24 September, 2012, from http://www.nacso.org.na/SOC_profiles/Registered\%20Communal\%20Conservancies.pdf 
Nuggehalli, R. K., \& Prokopy, L. S. (2009). Motivating factors and facilitating conditions explaining women's participation in co-management of Sri Lankan forests. Journal of Forest Policy and Economics, 11, 288-293. http://dx.doi.org/10.1016/j.forpol.2009.05.002

Paterson, B., Stuart-Hill, G., Underhill, L. G., Dunne, T. T., Schinzel, B., Brown, C., ... Weaver, C. (2008). A fuzzy decision support tool for wildlife translocations into communal conservation in Namibia. Environmental Modeling \& Software, 23, 521-534. http://dx.doi.org/10.1016/j.envsoft.2007.07.005

Reed, M. (2008). Stakeholder participation for environmental management: A literature review. Journal of Biological Conservation, 141, 2417-2431. http://dx.doi.org/10.1016/j.biocon.2008.07.014

Ritchie, J. R. B. (1985). The Nominal Group Technique-An approach to consensus policy formulation in Tourism. Journal of Tourism Management, 6(2), 82-94. http://dx.doi.org/10.1016/0261-5177(85)90017-2

Rozemeijer, N., \& van der Jagt, C. (2000). Community-based natural resources management (CBNRM) in Botswana: How community based is CBNRM in Botswana? In S. Shackleton, \& B. Campbell (Eds), Empowering Communities to Manage Natural Resources: Case Studies from Southern Africa. South Africa: USAID SADC NRM.

Sanderson, E., \& Kindon, S. (2004). Progress in participatory development: opening up the possibility of knowledge through progressive participation. Progress in Development Studies, 4(2), 114-126.

Sullivan, S. (2002). How sustainable is the communalising discourse of 'new' conservation? The masking of difference, inequality and aspiration in the fledgling 'conservancies' of Namibia. In D. Chatty, \& M. Colchester (Eds), Conservation and mobile indigenous peoples. Displacement, forced settlement and sustainable development. Oxford: Berghahn Books.

Zinn, H., Mosimane, A., \& Duarte, M. (2010). Wildlife tourism, community-based natural resource management, wildlife value orientations, and quality of life indicators in indigenous Namibian villages in Recreation, tourism and nature in a changing world. The Fifth International Conference on Monitoring and Management of Visitor Flows in Recreational and Protected Areas, Wageningen, The Netherlands, 30 May-3 June 2010, Edited by Martin Goossen, Birgit Elands and Ramona van Marwijk. 